\title{
Designing of Inventory Control for Aluminum Industry
}

\author{
Ineu Widaningsih Sosodoro ${ }^{1}$, Anastasia Lidya Maukar ${ }^{1}$, Intan Puspita Pribadi ${ }^{1}$ \\ 1) Industrial Engineering Department, Faculty of Engineering, President University \\ Jl. Ki Hajar Dewantara \\ Kota Jababeka,Cikarang, Bekasi - Indonesia 17550 \\ Email: inesosodoro@yahoo.co.id, almaukar@gmail.com, intanpuspita.pribadi@aiesec.net
}

\begin{abstract}
Inventory is one of important factors in manufacturing industry to ensure production process run. This research was conducted in an aluminum ingot manufacture company. The company faces a problem to manage the inventory system for their main raw material. The problem deals with the high expenditure due to safety stock that causes high inventory cost. Total inventory cost based on current condition is $\$ 270,706$ per year. The proposed improvement method that used in this analysis is continuous review system. This method is applied to determine the appropriate Reorder Point (ROP) and to minimize the inventory cost. Based on the proposed improvement, total inventory cost can be reduced by $30 \%$. This proposed system is also equipped with Decision Support System by using what-if analysis method as the tool to make decision for the next several periods by giving several scenarios and considering the aspects that influence to decision.
\end{abstract}

Keywords: Inventory, Reorder point, Continuous Review System, Decision Support System, What If Analysis, Scenario

\begin{abstract}
ABSTRAK
Persediaan adalah salah satu faktor penting dalam menjalankan produksi. Penelitian ini dilakukan di suatu perusahaan pembuatan aluminium dan perusahaan saat ini menghadapi permasalahan dengan tingginya tingkat persediaan yang mengakibatkan tingginya biaya persediaan yaitu sebesar $\$ 270.706$ per tahun. Sistem persediaan diusulkan dengan menggunakan continuous review system dan juga penentuan reorder point. Dengan usulan sistem persediaan batu, didapatkan penurunan total biaya persediaan sebesar 30 persen. Selain itu usulan ini juga dilengkapi dengan Decision Support System dengan menggunakan metode what-if analysis sebagai alat bantu pengambilan keputusan beberapa periode ke depan dengan menggunakan berbagai scenario dan pertimbangan yang dapat mempengaruhi keputusan
\end{abstract}

Keywords: persediaan, Reorder point, Continuous Review System, Decision Support System, What If Analysis, Scenario

\section{Introduction}

Inventory is one of the most expensive assets in a company, usually around $40 \%$ of total investment (Deitiana, 2011). It used to ensure an efficiency of capital utilization and process optimization in order to give benefit to company. One of the crucial aspects of efficiency in inventory management is inventory control. It applies coordination of material accessibility, controlling, utilization and procuring. Inventory management is held to control inventory in order to serve consumers' needs time by time as well as to minimize the total cost of a company's operations. The company concerns in processing of ingot smelter aluminum. The process to produce aluminium is shown in the Figure 1.

Bauxite is one of Indonesia natural resources, but Indonesia does not have facility to convert it into alumina. As the consequence, Indonesia should export to get alumina and process it into aluminium. The ratio of Bauxite:Alumina:Aluminium is 4:2:1. The Alumunium demand in Indonesia is 250,000 MTON per year. Since alumina is imported, it needs a certain period of lead time which is 9 days with the details are 1 day for open pre order, 1 day for exporting from origin, 5 days for transporting by sea and 2 days are import release. Sometimes it is longer than has been determined which causing shortage. In last 3 years during 2012, shortage becomes the one of significant issue since it gives an extra inventory cost. This condition also becomes worst due to rupiah currency rate is lower than dollar currency rate. Based on the problem above it can be summarized that the company is still lack of inventory optimalization. An ideal inventory system 
should be made to solve the problem. Inventory problem will be more complicated if there are many uncertain factors.

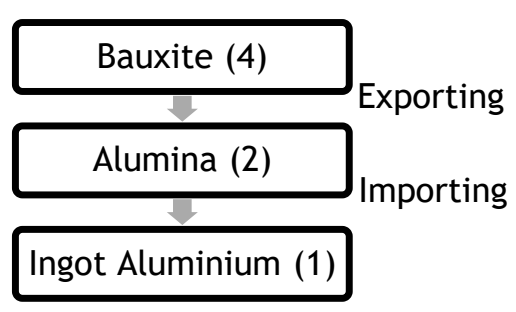

Figure 1. Aluminium Production Process

To be able to compete with others, high efficiency is being necessity, a good computerized inventory system is indispensable for achieving the efficiency by decision support system. Decision Support System can be defined as a system which is applied to support decision making process that used by managers in complex condition (Turban, et al, 2005). By this, the process become more integrated and can be used easily, quickly, and accurately. What if analysis will apply into DSS to develop the system. It has a purpose to analyze the characteristics of a complex system based on the hypothesis (Golfareli, et al, 2006). It can be used to determine the changes of dependent variables if there is a change to independent variables, (Philippakis, 1988). By this simulation model, it will generate some scenarios, each of them describing alternative ways to construct a prediction of interest for the user. Each scenario may give a different simulation, (Golfarelli and Rizzi, 2008).

\section{Method}

Figure 2 below shows the research process procedure. In problem identification, problem is mapped to be more detail what was happen to the company. Then, the inventory model was conducted by identifying an appropriate model based on company's current condition. There are many decision process in this stage. Collecting data is used to gather the informations related to research problem. These data will be use to get an understanding of interest area or problem scope and to support formulating solution. The next process afte is manual computation. The Q, r Model will compute manually based on this current condition. The result of this computation will be used for the next stage. There are several step to compute this method (Sipper \& Bulfin Jr., 1997):

Step 0 : Set $j=0$.

Step 1 : Consider $\bar{b}(R)=0$ and calculate $Q_{0}$ by deterministic method using Equation (1).

$$
Q_{0}=\sqrt{\frac{2 A \bar{D}}{h}}
$$

Step 2 : Determining $R_{0}$ using standardized normal distribution to find $F_{z}$ using Equation (2)

$$
1-F_{z}=\frac{h Q_{0}}{\pi \bar{D}}
$$

Based on the table of area under the normal curve, $z$ value can be determined. The manual formula to find this $z$ score is $\frac{1}{\sqrt{2 \pi}} e^{-\left(\frac{1}{2}\right) z^{2}}$. Then, $R_{0}$ can be computed using Equation (3)

$$
R_{0}=\bar{D}_{\tau}+z \sigma_{\tau}
$$

Step 3 : Calculate max. backorder level, based on the table of unit normal linear loss integral $\left(L_{z}\right)$ Step 4 : Calculate new order quantity

$$
Q_{1}=\sqrt{\frac{2 x \bar{D}\left(A+\pi \bar{b}\left(R_{0}\right)\right.}{h}}
$$

Step 5 : Use $Q_{1}$ to find $R_{1}$. Based on the table of area under the normal curve, $\mathrm{z}$ value can be determined. Then $R_{1}$ can be defined.

$$
1-F_{z}=\frac{h Q_{1}}{\pi \bar{D}}
$$

Step 6 : Since $R_{1}=R_{2}$, so the iteration is stopped till here. If the value of them are not equal so the iteration should be continued.

According to Equation (1)- Equation (5) above, total inventory cost can be calculated using Equation (6)

Where,

$$
T I C=A \frac{D}{Q}+h\left(\frac{Q}{2}+R-\bar{D}_{\tau}\right)+\frac{\pi \bar{D} \bar{b}(R)}{Q}
$$

$\mathrm{A} \quad=$ ordering cost

D = annual demand 
Q $\quad=$ optimum quantity order

$\mathrm{h} \quad=$ holding cost

$\mathrm{R} \quad$ = reorder Point

$\bar{D}_{\tau} \quad=$ average daily demand

$\frac{\pi \bar{D} \bar{b}(R)}{Q} \quad$ =stock out cost

Then, comparing the solution between current condition and proposed model is performed. It is used to see which is the best solution to solve the problem and how good it is to be implemented. The best result will consider as the data input system using Microsoft Excel 2013. According to the problem explanation, there are some uncertainties factor such as shortage, lead time and currency rate dollar. Since currency rate dollar is affecting to the ordering cost, holding cost and stock out cost variable so there will be 5 parameter variables such as Lead time, Currency Rate, Ordering Cost, Holding Cost, and Stock Out Cost. Each of them has three level such as if it is increase, decrease or same. Therefore the total scenario will be $3^{5}$ or 243 scenario. This combination scenario will be used as the data input for what if analysis using Microsoft Excel. In Inventory Model Simulation, all of the scenario will simulate using What If analysis in Ms. Excel 2013. This simulation will generate some alternative solutions. Then the output will be interpreted. Interpretation is used to explain the data output based on inventory model simulation process. The output of this simulation process can be used as the decision tool for the company based on user interest criteria.

\section{Result and Discussion}

\section{Annual Demand}

During 2016, the total demand of Alumunium for Indonesia is about 250,000 MTON. The ratio between Alumunium and Alumina is 1:2. Table 1 below shows the demand of alumnia during 2016.

Table 1 Demand in Year 2016

\begin{tabular}{|l|c|c|c|}
\hline Period & Alumunium & Alumina & Operation Day \\
\hline January & 20,684 & 40,540 & 31 \\
\hline February & 18,816 & 36,880 & 28 \\
\hline March & 21,049 & 41,256 & 31 \\
\hline April & 20,581 & 40,338 & 30 \\
\hline May & 21,483 & 42,107 & 31 \\
\hline June & 20,749 & 40,668 & 30 \\
\hline July & 21,440 & 42,023 & 31 \\
\hline August & 21,440 & 42,023 & 31 \\
\hline September & 20,749 & 40,668 & 30 \\
\hline October & 21,440 & 42,023 & 31 \\
\hline November & 20,496 & 40,172 & 30 \\
\hline December & 21,179 & 41,511 & 31 \\
\hline Total & 250,107 & 490,209 & 365 \\
\hline Average & 20,842 & 40,851 & 30 \\
\hline
\end{tabular}

\section{Variable Cost of Inventory}

There are three kind of variables cost of inventory to support the data analysis which is shown in the Figure 3 below 


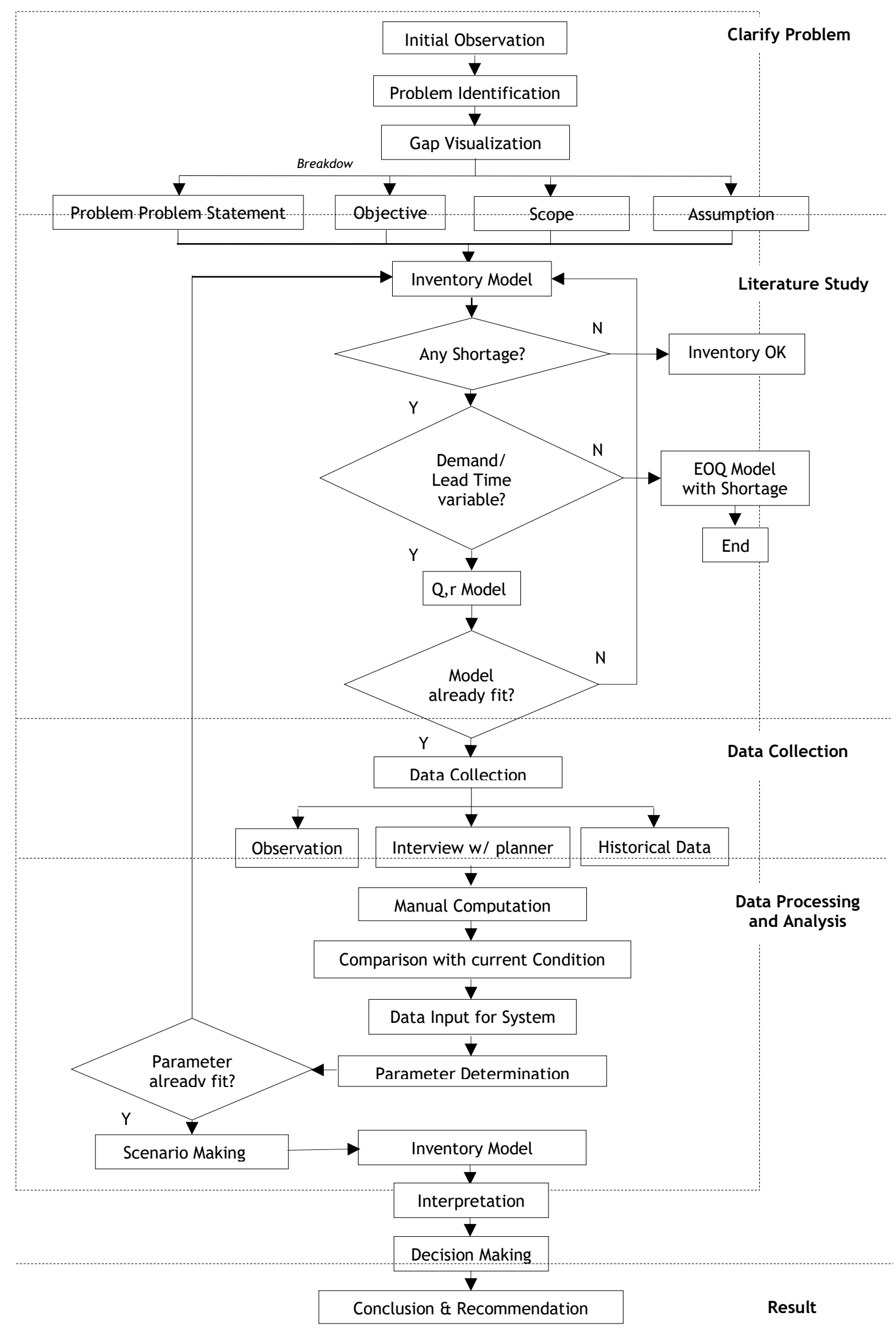

Figure 2. Flowchart of Research Steps 


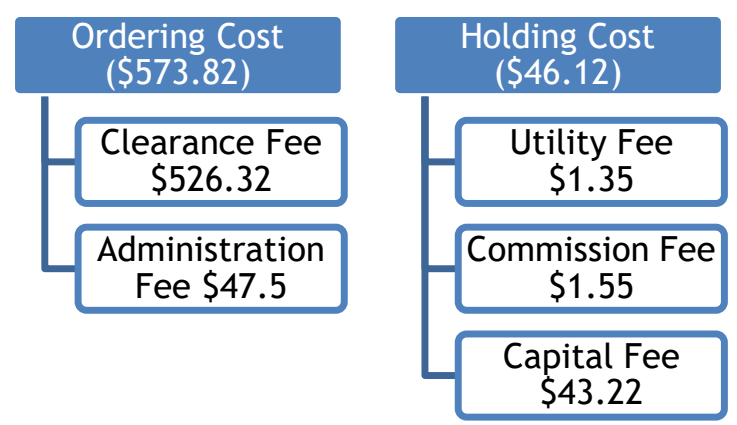

\section{Stock Out Cost} $(\$ 0.45)$

Figure 3. Variable Cost

The ordering cost of this raw material consists of clearance fee and administration fee. Administration fee is an expense that burdened to the company due to documents of the raw material. Clearance fee is an expense that burdened to the company to clear all the administrative term in harbor without direct connecting with company (external party). Utility expenses are burdened by another three variable such as building depreciation, electricity and maintenance. Utility is cost consumed due to electricity, warehouse and maintenance expenditure. Commission fee is an expense that will be charged by an agent for his service in managing the raw material in warehouse. While capital fee is opportunity cost issued by the company that calculated as an alternative income on inventory investment. Stock out cost is an economic consequences due to shortage occurrence. Stock out cost is the average cost of stock-out costs in the last three years during 2012.

\section{Total Inventory Cost}

The order quantity can be defined according to demand during 2015 which is 490,209 MTON, so it will be 3,493 MTON.

$$
Q_{\text {optimum }}=\sqrt{\frac{2 A \bar{D}}{h}}=\sqrt{\frac{2 \times 573,82 \times 490,209}{46,12}}=3,493 \text { MTON }
$$

The company assumed that in 2016 the service level can be achieved into 95\%. Therefore, the company should be storing 2,377 MTON as the safety stocks.

The total inventory cost is:

$$
R O P=\mu+z \sigma=40,851+1.645 * 1445=43,228 \text { MTON }
$$

$$
\begin{gathered}
\text { Ordering Cost }=A \frac{D}{Q}=573.82 x \frac{490,209}{3493}=\$ 80,530 \\
\text { Holding Cost }=h \frac{Q}{2}=46.12 x \frac{3493}{2}=\$ 80,549 \\
\text { Safety Stock cost }=S S x h=2,377 x 46,12=\$ 109,627 \\
\text { Inventory Cost }=\$ 80,530+\$ 80,549+\$ 109,627=\$ 270,706
\end{gathered}
$$

\section{Proposed Model (Q,R System)}

The propose inventory model will be used by using $\mathrm{Q}, \mathrm{R}$ model. In the continuous review system, the decision variables are quantity order $(\mathbf{Q})$ and reorder point $(\mathbf{R})$. There are several steps that should be conducted to calculate inventory cost using this model:

Step 0 : Set $j=0$.

Step 1 : Consider $\bar{b}(R)=0$ and calculate $Q_{0}$ by deterministic method.

$$
Q_{0}=\sqrt{\frac{2 A \bar{D}}{h}}=\sqrt{\frac{2 \times 573,82 \times 490,209}{46,12}}=3,493 \text { MTON }
$$

Step 2 : Determining $R_{0}$ using standardized normal distribution to find $F_{z}$

$$
1-F_{z}=\frac{h Q}{\pi \bar{D}}=\frac{46.12 \times 3,493}{53 \times 490,209}=0.0062
$$

So $F_{Z}$ is 0.9938 . Based on the table of area under the normal curve, it is show that its value refer to $z=2.50$. The manual formula to find this $z$ score is $\frac{1}{\sqrt{2 \pi}} e^{-\left(\frac{1}{2}\right) z^{2}}$. Then,

Where $\bar{D}_{\tau}=490,209 \times \frac{9}{365}=12,087$ MTON

$$
R_{0}=\bar{D}_{\tau}+z \sigma_{\tau}
$$




$$
R_{0}=12,087+2.50\left(1,445 x \sqrt{\frac{9}{365}}\right)=12,654 \text { MTON }
$$

Step 3 : Calculate maximum backorder level, based on the table of unit normal linear loss integral $\left(L_{z}\right), L_{2.50}$ is 0.0020 . Therefore,

\section{$1^{\text {st }}$ Iteration}

$$
\bar{b}\left(R_{0}\right)=\sigma_{\tau} L_{z}=\left(1,445 x \sqrt{\frac{9}{365}}\right) \times 0.0020=0.4565
$$

Step 4 : Calculate new order quantity

Step 5 : Use $Q_{1}$ to find $R_{1}$

$$
Q_{1}=\sqrt{\frac{2 x \bar{D}\left(A+\pi \bar{b}\left(R_{0}\right)\right.}{h}}=\sqrt{\frac{2 x 490,209 \times(573.82+(53 \times 0.4565))}{46.12}}=3,564 \text { MTON }
$$

$$
1-F_{z}=\frac{h Q}{\pi \bar{D}}=\frac{46.12 \times 3,564}{53 \times 490,209}=0.0063
$$

So $F_{z}$ is 0.9937 . Based on the table of area under the normal curve, it is show that its value refer to $z=2.49$. The manual formula to find this $z$ score is $\frac{1}{\sqrt{2 \pi}} e^{-\left(\frac{1}{2}\right) z^{2}}$. Then,

\section{$2^{\text {nd }}$ Iteration}

$$
R_{1}=12.087+2.49\left(1,445 x \sqrt{\frac{9}{365}}\right)=12,652 \text { MTON }
$$

Step 6 : Calculate maximum backorder level, based on the table of unit normal linear loss integral $\left(L_{z}\right), L_{2.49}$ is 0.0020 . Therefore,

Step 7 : Calculate new order quantity

$$
\bar{b}\left(R_{1}\right)=\sigma_{\tau} L_{z}=\left(1,445 x \sqrt{\frac{9}{365}}\right) \times 0.0020=0.4566
$$

$$
Q_{2}=\sqrt{\frac{2 x \bar{D}\left(A+\pi \bar{b}\left(R_{1}\right)\right.}{h}}=\sqrt{\frac{2 x 490,209 \times(573.82+(53 \times 0.4566))}{46.12}}=3,565 \text { MTON }
$$

Step 8 : Use $Q_{1}$ to find $R_{1}$

$$
1-F_{z}=\frac{h Q}{\pi \bar{D}}=\frac{46.12 \times 3,565}{53 \times 490,209}=0.0063
$$

So $F_{z}$ is 0.9937 . Based on the table of area under the normal curve, it is show that its value refer to $z=2.49$. The manual formula to find this $z$ score is $\frac{1}{\sqrt{2 \pi}} e^{-\left(\frac{1}{2}\right) z^{2}}$. Then,

$$
R_{2}=12.087+2.49\left(1,445 x \sqrt{\frac{9}{365}}\right)=12,652 \text { MTON }
$$

Step 9 : Since $R_{1}=R_{2}$, so the iteration is stopped till here. Where the $(\mathrm{Q}, \mathrm{r})$ is $(3,565 ; 12,652)$. It can be concluded as below:

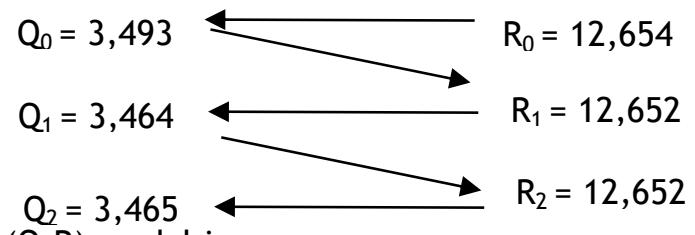

Safety stock by using $(Q, R)$ model is:

Service level is:

$$
\text { Safety Stock }=2.49\left(1,445 x \sqrt{\frac{9}{365}}\right)=565 \text { MTON }
$$

$$
\begin{gathered}
z=\frac{x-\mu}{\sigma}=\frac{R-\bar{D}_{\tau}}{\sigma_{\tau}}=\frac{12,652-12,087}{\left(1,445 x \sqrt{\frac{9}{365}}\right)}=2.49 \\
F(z \leq 2.49) \approx 0.9937=99.37 \%
\end{gathered}
$$


Therefore, based on the procedure above, the inventory cost is $\$ 190,497$ :

$$
\begin{gathered}
\text { Ordering Cost }=573.82 \times \frac{490,209}{3,565}=\$ 78,893 \\
\text { Holding Cost }=46.12\left(\frac{3,565}{2}+12,652-\left(490,209 \times \frac{9}{365}\right)\right)=\$ 108,275 \\
\text { Stockout Cost }=\frac{53 \times 490,209 \times 0.45}{3,565}=\$ 3,329 \\
\text { TIC }=\$ 78,928+\$ 108,240+\$ 3,329=\$ 190,497
\end{gathered}
$$

\section{Comparison Method}

Based on proposed model, the company can achieve higher service level with lower inventory cost as shown in Table 3 below:

Table 3 Comparison of Total Inventory Cost

\begin{tabular}{|l|r|r|}
\hline Variable Cost & Company’s Policy & Continuous Method \\
\hline Ordering Cost & $\$ 80,530$ & $\$ 78,893$ \\
\hline Holding Cost & $\$ 80,549$ & $\$ 108,275$ \\
\hline Safety Stock & $\$ 109,627$ & - \\
\hline Stock out Cost & - & $\$ 3,329$ \\
\hline Total Inventory Cost (\$) & $\$ 270,706$ & $\$ 190,497$ \\
\hline Total Inventory Cost (IDR) & IDR3,707,047,964 & IDR2,608,666,212 \\
\hline Service Level & $95 \%$ & $99,37 \%$ \\
\hline
\end{tabular}

\section{Parameter Set}

For parameter, it is assumed that there are five variables that chosen as the input for scenario such as money rate (MR), Ordering Cost (OC), Holding Cost (HC), Stock Out Cost (SO), and Lead Time (LT). All of them would be changed into three condition such as how if it is increase (I), same (S) or decrease (D). The details is referred to Table4.

Table 4. Variable of Scenario

\begin{tabular}{|l|r|r|r|}
\hline Variable & \multicolumn{1}{|c|}{ Increase } & \multicolumn{1}{|c|}{ Same } & \multicolumn{1}{c|}{ Decrease } \\
\hline MR & IDR14,500 & IDR13,694 & IDR12,500 \\
\hline OC & $\$ 580.7$ & $\$ 573.82$ & $\$ 566.94$ \\
\hline HC & $\$ 53$ & $\$ 46.12$ & $\$ 39.24$ \\
\hline SO & $\$ 59.88$ & $\$ 53$ & $\$ 46.12$ \\
\hline LT & 14 Days & 9 Days & 7 Days \\
\hline
\end{tabular}

The assumption for variable cost above will change around $\pm \$ 6.88$. It is the difference amount of holding cost and stock out cost. Since there are five variables, so there will be $3^{5}(243)$ scenario combinations. These combinations will be used to plan the inventory cost for period January until June 2017. The demand for period January-June 2017 is shown in the Table 5 below:

Table 5. Demand Alumina in Year 2017

\section{$(Q, R)$ System of Next Period}

\begin{tabular}{|l|r|}
\hline Period 2017 & Demand \\
\hline January & 41,852 \\
\hline February & 39,470 \\
\hline March & 42,533 \\
\hline April & 41,161 \\
\hline May & 42,533 \\
\hline June & 41,161 \\
\hline Total & 248,710 \\
\hline
\end{tabular}

Based on the next period demand above, the $(\mathrm{Q}, \mathrm{R})$ system can be calculated as follows:

Step 0 : Set $j=0$.

Step 1 : Consider $\bar{b}(R)=0$ and calculate the initial order quantity by deterministic method.

$$
Q_{0}=\sqrt{\frac{2 A \bar{D}}{h}}=\sqrt{\frac{2 \times 573,82 \times 248,710}{46,12}}=2,488 \text { MTON }
$$

Step 2 : Determining $R_{0}$ using standardized normal distribution to find $F_{z}$ 


$$
1-F_{z}=\frac{h Q}{\pi \bar{D}}=\frac{46.12 \times 2,488}{53 \times 248,710}=0.0087
$$

So $F_{z}$ is 0.9913 . Based on the table of area under the normal curve, it is show that its value refer to $z=2.38$. The manual formula to find this $z$ score is $\frac{1}{\sqrt{2 \pi}} e^{-\left(\frac{1}{2}\right) z^{2}}$. Then,

Where $\bar{D}_{\tau}=248,710 \frac{9}{182}=12,299$ MTON

$$
R_{0}=\bar{D}_{\tau}+z \sigma_{\tau}
$$

$$
R_{0}=12,299+2.38\left(1,048 x \sqrt{\frac{9}{182}}\right)=12,853 \text { MTON }
$$

Step 3 : Calculate maximum backorder level, based on the table of unit normal linear loss integral $\left(L_{z}\right), L_{2.38}$ is 0.0029 . Therefore,

\section{$1^{\text {st }}$ Iteration}

$$
\bar{b}\left(R_{0}\right)=\sigma_{\tau} L_{z}=\left(1,048 x \sqrt{\frac{9}{182}}\right) \times 0.0029=0.6692
$$

Step 4 : Calculate new order quantity

$$
Q_{1}=\sqrt{\frac{2 x \bar{D}\left(A+\pi \bar{b}\left(R_{0}\right)\right.}{h}}=\sqrt{\frac{2 \times 248,710 \times(573.82+(53 \times 0.6692))}{46.12}}=2,563 \text { MTON }
$$

Step 5 : Use $Q_{1}$ to find $R_{1}$

$$
1-F_{z}=\frac{h Q}{\pi \bar{D}}=\frac{46.12 \times 2,563}{53 \times 248,710}=0.0090
$$

So $F_{z}$ is 0.9910 . Based on the table of area under the normal curve, it is show that its value refer to $z=2.37$. The manual formula to find this $z$ score is $\frac{1}{\sqrt{2 \pi}} e^{-\left(\frac{1}{2}\right) z^{2}}$. Then,

\section{$2^{\text {nd }}$ Iteration}

$$
R_{1}=12,299+2.37\left(1,048 x \sqrt{\frac{9}{182}}\right)=12,851 \text { MTON }
$$

Step 6 : Calculate maximum backorder level, based on the table of unit normal linear loss integral $\left(L_{z}\right), L_{2.37}$ is 0.0030 . Therefore,

Step 7 : Calculate new order quantity

$$
\bar{b}\left(R_{1}\right)=\sigma_{\tau} L_{z}=\left(1,048 x \sqrt{\frac{9}{365}}\right) \times 0.0030=0.6919
$$

$$
Q_{2}=\sqrt{\frac{2 x \bar{D}\left(A+\pi \bar{b}\left(R_{1}\right)\right.}{h}}=\sqrt{\frac{2 x 248,710 \times(573.82+(53 \times 0.6919))}{46.12}}=2,566 \text { MTON }
$$

Step 8 : Use $Q_{1}$ to find $R_{1}$

$$
1-F_{z}=\frac{h Q}{\pi \bar{D}}=\frac{46.12 \times 2,566}{53 \times 248,710}=0.0090
$$

So $F_{z}$ is 0.9910 . Based on the table of area under the normal curve, it is show that its value refer to $z=2.37$. The manual formula to find this $z$ score is $\frac{1}{\sqrt{2 \pi}} e^{-\left(\frac{1}{2}\right) z^{2}}$. Then,

$$
R_{2}=12.299+2.37\left(1,048 x \sqrt{\frac{9}{365}}\right)=12,850 \text { MTON }
$$

Step 9 : Since $R_{1}=R_{2}$, so the iteration is stopped till here. Where the $(\mathrm{Q}, \mathrm{r})$ is $(2,566 ; 12,851)$. It can be concluded as below:

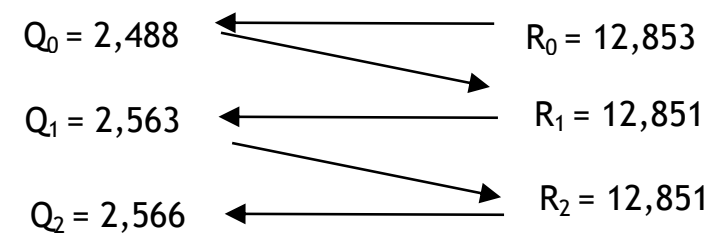


Step 6 : Since $R_{0}=R_{1}$, so the iteration is stopped till here. Where the $(\mathrm{Q}, \mathrm{r})$ is $(2,566 ; 12,851)$. Therefore, the inventory cost is shown in the details below:

$$
\begin{gathered}
\text { Ordering Cost }=573.82 \times \frac{248,710}{2,566}=\$ 55,618 \\
\text { Holding Cost }=46.12\left(\frac{2,566}{2}+12,851-\left(248,710 \times \frac{9}{182}\right)\right)=\$ 84,621 \\
\text { Stockout Cost }=\frac{53 \times 248,710 \times 0.6692}{2,566}=\$ 3,554 \\
\text { TIC }=\$ 55,618+\$ 84,621+\$ 3,554=\$ 143,793
\end{gathered}
$$

After identifying parameter set of inventory, the scenario will be made for further calculation. These parameters will be used as the input and the inventory cost will be set as the output. These input and output numbers will be entered in scenario. Here, scenario is created to observe changes in inventory cost after analyzing its parameter. This tool will use to make a simulation due to inventory cost. Simulation software are using to evaluate, compare and optimize alternative designs or plans.

\section{Simulation Model \\ Data Output}

According to the simulation output, parameters are affecting to quantity order $(\mathrm{Q})$, reorder point (ROP), Satisfaction Level, Total Ordering Cost, Total holding Cost, Total Stock Out Cost and Total Inventory Cost Scenario 122 is showing the actual condition in the company. The first

\begin{tabular}{|c|c|c|c|}
\hline Scenario Summary & Scenario 95 & Scenario 122 & Scenario 149 \\
\hline \multicolumn{4}{|l|}{ Changing Cells: } \\
\hline Ordering Cost & USD 581 & USD 574 & USD 567 \\
\hline Holding Cost & USD 46 & USD 46 & USD 46 \\
\hline Stock Out Cost & USD 53 & USD 53 & USD 53 \\
\hline Rate Dollar & IDR 13,694 & IDR 13,694 & IDR 13,694 \\
\hline Lead Time & 9 & 9 & 9 \\
\hline \multicolumn{4}{|l|}{ Result Cells: } \\
\hline $\mathbf{Q}$ & 2,581 & 2,566 & 2,551 \\
\hline Reorder Point & 12,850 & 12,851 & 12,851 \\
\hline Service Level & $99.10 \%$ & $99.10 \%$ & $99.11 \%$ \\
\hline Total Ordering Cost & $766,305,766$ & $761,628,126$ & $756,922,448$ \\
\hline Total Holding Cost & $1,163,198,495$ & $1,158,805,128$ & $1,154,386,931$ \\
\hline Total Stock Out Cost & $48,704,220$ & $48,671,998$ & $48,639,440$ \\
\hline Total Inventory Cost & IDR 1,978,208,481 & IDR 1,969,105,252 & IDR $1,959,948,819$ \\
\hline
\end{tabular}
analysis of data output is figure out about fluctuating Ordering Cost, what will happen to the inventory cost if the ordering cost is increase or decrease even the same.

Table 7. Data Output based on Fluctuated Ordering Cost

According to the simulation output of scenario 95, scenario 122 and scenario 149 , it shows that if the ordering cost variable is increase, it will make the quantity order (Q), total ordering cost, total holding cost, total stock out cost and total inventory cost become higher. The higher value of ordering cost, the smaller value of reorder point (ROP) and service level. Scenario that have higher

\begin{tabular}{|c|c|c|c|c|c|c|}
\hline $\mathrm{Q} \uparrow$ & $\mathrm{ROP} \downarrow$ & Tot. Ordering Cost & $\begin{array}{l}\text { Tot. Holding } \\
\text { Cost } \uparrow\end{array}$ & $\begin{array}{l}\text { Tot. Stock } \\
\text { Out Cost } \uparrow\end{array}$ & $\begin{array}{c}\text { Total } \\
\text { Inventory } \uparrow\end{array}$ & $\begin{array}{c}\text { Service Level } \\
\downarrow\end{array}$ \\
\hline
\end{tabular}
ordering cost value makes reorder point lower than others and the service level is $99.097 \% \approx 99.10 \%$ lower than scenario 122 (99.103\%) and scenario 149 (99.108\%). It can be conluded as below:

Ordering Cost $\uparrow$

Figure 4. Conclusion Output based on Fluctuating Ordering Cost 
Based on the figure above, it can be summarized that if Ordering Cost is variable there will be a trade-off in $\mathrm{Q}$ which means that the more quantity of $\mathrm{R}$, the smaller $\mathrm{Q}$, and vice versa. In other words, if $\mathrm{Q}$ increases, the holding cost will increase and ordering cost decrease. If $\mathrm{R}$ decreases, the holding cost will decrease even when $\mathrm{R}$ is lower, it means that shortage cost would be higher. Then, the second analysis of data output is figured out the fluctuating Holding Cost.

Table 8. Data Output based on Fluctuating Holding Cost

\begin{tabular}{|c|c|c|c|}
\hline Scenario Summary & Scenario 113 & Scenario 122 & Scenario 131 \\
\hline \multicolumn{4}{|l|}{ Changing Cells: } \\
\hline Ordering Cost & USD 574 & USD 574 & USD 574 \\
\hline Holding Cost & USD 53 & USD 46 & USD 39 \\
\hline Stock Out Cost & USD 53 & USD 53 & USD 53 \\
\hline Rate Dollar & IDR 13,694 & IDR 13,694 & IDR 13,694 \\
\hline Lead Time & 9 & 9 & 9 \\
\hline \multicolumn{4}{|l|}{ Result Cells: } \\
\hline $\mathbf{Q}$ & 2,400 & 2,566 & 2,774 \\
\hline Reorder Point & 12,844 & 12,851 & 12,858 \\
\hline Service Level & $99,04 \%$ & $99.10 \%$ & $99,17 \%$ \\
\hline Total Ordering Cost & $814,428,637$ & $761,628,126$ & $704,399,462$ \\
\hline Total Holding Cost & $1,266,781,288$ & $1,158,805,128$ & $1,045,792,672$ \\
\hline Total Stock Out Cost & $56,379,371$ & $48,671,998$ & $41,035,166$ \\
\hline Total Inventory Cost & IDR 2,137,589,295 & IDR 1,969,105,252 & IDR 1,791,227,300 \\
\hline
\end{tabular}

According to the simulation output of scenario 113, scenario 122 and scenario 131, it shows that if the holding cost variable is increase, it will make the quantity order $(\mathrm{Q})$, Reorder Point (ROP) smaller but Total Ordering Cost, Total Holding Cost, Total Stock Out Cost and Total Inventory Cost become higher. It can be conluded in the Figure 5 below.

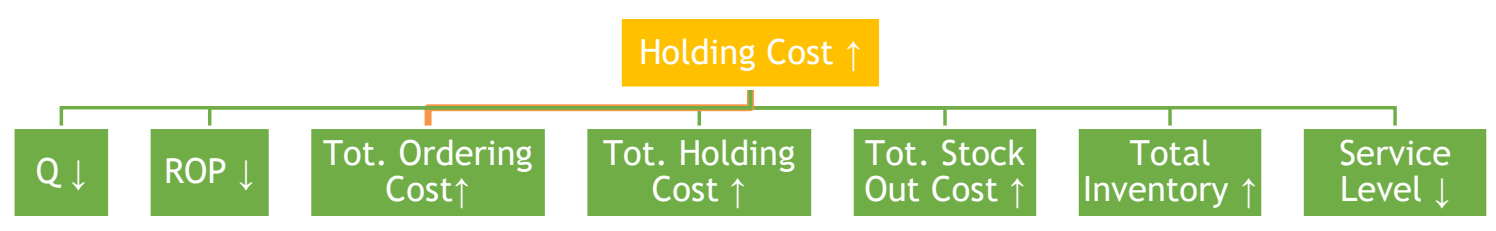

Figure 5. Conclusion Output based on Fluctuating Holding Cost

The third analysis of data output is figure out about fluctuating Stock Out Cost, what will happen to the inventory cost if the stock out cost is increase or decrease even the same.

According to the simulation output of scenario 119, scenario 122 and scenario 125, it shows that if the Stock Out cost variable is increase, it will make the quantity order $(\mathrm{Q})$ and Total Stock Out Cost smaller but Reorder Point, Satisfaction Level, Total Ordering Cost, Total Holding Cost, and Total Inventory Cost become higher. It can be conluded in the Figure 6 below.

Table 9. Data Output based on Fluctuated Stock Out Cost

\begin{tabular}{|c|c|c|c|}
\hline Scenario Summary & Scenario 119 & Scenario 122 & Scenario 125 \\
\hline \multicolumn{4}{|l|}{ Changing Cells: } \\
\hline Ordering Cost & USD 574 & USD 574 & USD 574 \\
\hline Holding Cost & USD 46 & USD 46 & USD 46 \\
\hline Stock Out Cost & USD 60 & USD 53 & USD 46 \\
\hline Rate Dollar & IDR 13,694 & IDR 13,694 & IDR 13,694 \\
\hline Lead Time & 9 & 9 & 9 \\
\hline \multicolumn{4}{|l|}{ Result Cells: } \\
\hline $\mathbf{Q}$ & 2,565 & 2,566 & 2,567 \\
\hline Reorder Point & 12,861 & 12,851 & 12,839 \\
\hline Service Level & $99,21 \%$ & $99.10 \%$ & $98,97 \%$ \\
\hline Total Ordering Cost & $761,946,193$ & $761,628,126$ & $761,252,391$ \\
\hline Total Holding Cost & $1,165,089,509$ & $1,158,805,128$ & $1,151,535,686$ \\
\hline Total Stock Out Cost & $48,015,678$ & $48,671,998$ & $49,447,676$ \\
\hline Total Inventory Cost & IDR $1,975,051,380$ & IDR $1,969,105,252$ & IDR $1,962,235,753$ \\
\hline
\end{tabular}




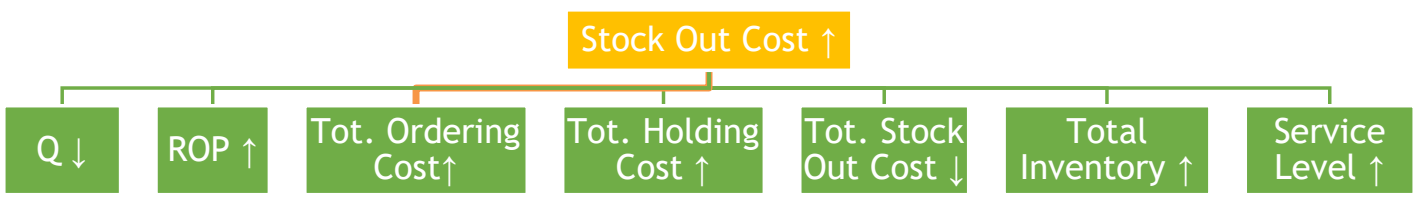

Figure 6. Conclusion Output based on Fluctuating Stock Out Cost

The fourth analysis of data output is figure out about fluctuating Dollar rate, what will happen to the inventory cost if the Rate Dollar is increase or decrease even the same.

Table 10. Data Output based on Fluctuating Dollar Rate

\begin{tabular}{|c|c|c|c|}
\hline Scenario Summary & Scenario 41 & Scenario 122 & Scenario 203 \\
\hline \multicolumn{4}{|l|}{ Changing Cells: } \\
\hline Ordering Cost & USD 574 & USD 574 & USD 574 \\
\hline Holding Cost & USD 46 & USD 46 & USD 46 \\
\hline Stock Out Cost & USD 53 & USD 53 & USD 53 \\
\hline Rate Dollar & IDR 14,500 & IDR 13,694 & IDR 12,500 \\
\hline Lead Time & 9 & 9 & 9 \\
\hline \multicolumn{4}{|l|}{ Result Cells: } \\
\hline $\mathbf{Q}$ & 2,566 & 2,566 & 2,566 \\
\hline Reorder Point & 12,851 & 12,851 & 12,851 \\
\hline Service Level & $99,10 \%$ & $99.10 \%$ & $99,10 \%$ \\
\hline Total Ordering Cost & $806,455,953$ & $761,628,126$ & $695,220,649$ \\
\hline Total Holding Cost & $1,227,009,958$ & $1,158,805,128$ & $1,057,767,205$ \\
\hline Total Stock Out Cost & $51,536,729$ & $48,671,998$ & $44,428,215$ \\
\hline Total Inventory Cost & IDR $2,085,002,640$ & IDR $1,969,105,252$ & IDR $1,797,416,069$ \\
\hline
\end{tabular}

According to the simulation output of scenario 41, scenario 122 and scenario 203, it shows that if the rate dollar variable is increase, it does not influence quantity order $(\mathrm{Q})$ and Reorder Point (ROP). As the consequence, the satisfaction level will be the same. It only influences on Total Ordering Cost, Total Holding Cost, Total Stock Out Cost and Total Inventory Cost. They become higher when dollar rate increases. It can be conluded in the Figure 6 below:

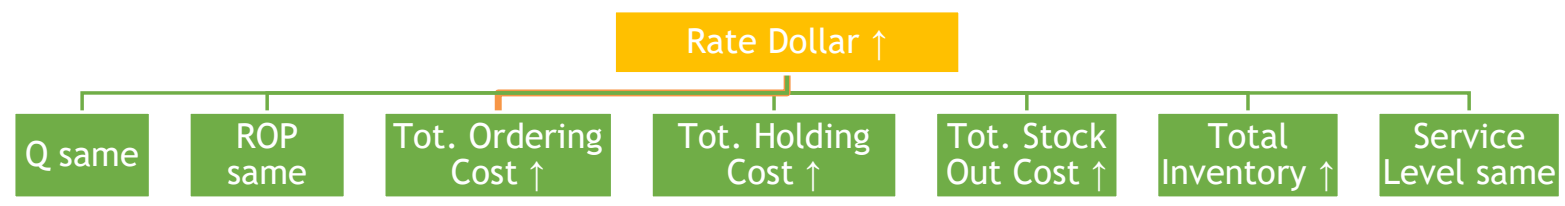

Figure 7. Conclusion Output based on Fluctuating Rate Dollar

The last analysis of data output is figure out about fluctuating Lead Time, what will happen to the inventory cost if the lead time is increase or decrease even the same.

Table 11. Data Output based on Fluctuating Lead Time

\begin{tabular}{|c|c|c|c|}
\hline Scenario Summary & Scenario 121 & Scenario 122 & Scenario 123 \\
\hline \multicolumn{4}{|l|}{ Changing Cells: } \\
\hline Ordering Cost & USD 574 & USD 574 & USD 574 \\
\hline Holding Cost & USD 46 & USD 46 & USD 46 \\
\hline Stock Out Cost & USD 53 & USD 53 & USD 53 \\
\hline Rate Dollar & IDR 13,694 & IDR 13,694 & IDR 13,694 \\
\hline Lead Time & 14 & 9 & 7 \\
\hline \multicolumn{4}{|l|}{ Result Cells: } \\
\hline Q & 2,586 & 2,566 & 2,557 \\
\hline Reorder Point & 19,819 & 12,851 & 10,053 \\
\hline Service Level & $99.10 \%$ & $99.10 \%$ & $99.11 \%$ \\
\hline Total Ordering Cost & $755,812,858$ & $761,628,126$ & $764,421,705$ \\
\hline Total Holding Cost & $1,250,710,930$ & $1,158,805,128$ & $1,114,857,122$ \\
\hline Total Stock Out Cost & $60,721,761$ & $48,671,998$ & $42,917,177$ \\
\hline Total Inventory Cost & IDR 2,067,245,550 & IDR $1,969,105,252$ & IDR 1,922,196,004 \\
\hline
\end{tabular}


According to the simulation output of scenario 121 , scenario 122 and scenario 123 , it shows that if the lead time variable is increase, it will make quantity order $(\mathrm{Q})$ and Reorder Point (ROP) increase. The longer lead time, the bigger quantity order $\mathrm{Q}$ will be placed. As the consequence, if lead time is longer, Total Holding Cost, Total Stock Out Cost and Total Inventory Cost become higher while Ordering Cost and Satisfaction Level become lower. It can be conluded Figure 8 below:

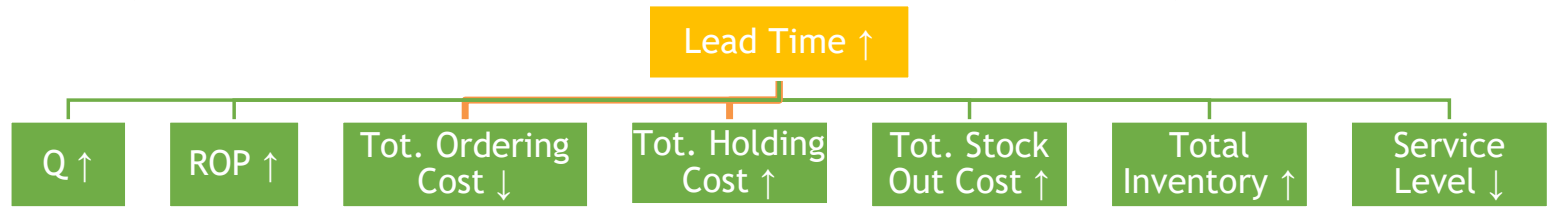

Figure 8. Conclusion Output based on Fluctuating Lead Time

\section{Conclusion}

Current condition, the company has a big expenditure due to safety stock. Total inventory cost of during 2016 is $\$ 270,706$ with the service level is $95 \%$. Based on the proposed improvement model using continuous review system, the total inventory cost can be reduced into $\$ 190,497$ which is around $30 \%$. In addition, this propose model also can improve the service level into $99 \%$. This model were made into varies scenario input to the system that will be simulated using Decision Support System. This system has been successfully develop the what if analysis for helping decision making process based on decision maker interest criteria. According to the simulation output, a decision maker should be careful to definee the purpose such as:

1. To minimize the shortage cost, $\mathrm{R}$ should be greater.

2. To minimize holding cost, $\mathrm{Q}$ and $\mathrm{R}$ should be smaller.

3. To minimize ordering cost, $Q$ should be greater.

In order to improve the future research, there are some recommendations:

1. System can be integrated using Microsoft Excel VBA (Visual Basic) and Microsoft Access.

2. System can be used to develop another model inventory using difference probability distribution model such as Single Period and Fixed Order, so the comparison process will be more easier.

3. System can be adjusted based on the situation characteristic such as Demand is constant while Lead Time is variable, Demand is variable while Lead time is Constant or both of Demand and Lead time are variables.

\section{References}

1. Deitiana, T. (2011) Manajemen Operasional Strategi dan Analisa (Servis dan Manufaktur), Mitra Wacana Media, Jakarta/

2. Golfarelli, M., and Rizzi, S. (2008). What If Simulation Modeling in Business Intelligence, International Journal of Data Warehousingg and Mining, December, Vol. 10, No. 10, pp. 1-16.

3. Golfarelli, M., and Rizzi, S., and Proli, A. (2006). Designing What If Analysis: Towards a Methodology, Proceedings of the 9th ACM International Workshop on Data Warehousing and OLAP, New York, retrived from http://bias.csr.unibo.it on 14 October 2016.

4. Philippakis, A. S., (1998). Structured What If Analysis in Decision Support System Models, Proceedings of the Twenty-First Annual Hawaii International Conference, Kailua-Kona, USA, retrived from http: / /ieeexplore.ieee.org on 02 October 2016.

5. Sipper, D., and Jr., Robert L. Bulfin., (1997). Production Planning, Control and Integrations, McGraw Hill, New York.

6. Turban, E., Aronson, Jay E., and Liang, T.P., (2005). Decision Support Systems and Intelligent Systems, $7^{\text {th }}$ edition., Pearson Prentice Hall, New Jersey. 